\title{
TRANSFORMATIONAL LEADERSHIP OF DAYAH: EMPOWERMENT OF DAYAH COMMUNITY IN DEVELOPING TOTAL QUALITY MANAGEMENT
}

\author{
Almuhajir' ${ }^{1}$ Jumat Barus ${ }^{2}$ \\ ${ }^{1}$ Pascasarjana IAIN Lhokseumawe, ${ }^{2}$ FTIK IAIN Lhokseumawe \\ 1,2 Jalan Medan-Banda Aceh. Alue Awee, Kota Lhokseumawe \\ Email: abujaadalhaq@yahoo.com ${ }^{1}$, jumatbarus@iainlhokseumawe.ac.id ${ }^{2}$
}

\begin{abstract}
:
This study aims to explain the transformational leadership of Dayah in empowering the Dayah community, which is focused on empowering the quality of teungku, santri, and administrative personnel for the development of Total Quality Management (QTM). The research method used was library research with a transformational leadership approach to educational institutions. Data sources consisted of books, journals, and other literacy sources related to Dayah educational institutions and transformational leadership. Data analysis used was content analysis by determining, describing, and interpreting the data. The result indicated that to empower teungku quality, Dayah leaders carry out the management, guidance and development of all teungku in the intellectual, spiritual, emotional and social dimensions. To empower the quality of students, Dayah leaders organize all activities related to the students, from input to output, with a series of cognitive, affective, and psychomotor activities. Empowerment of administrative personnel, Dayah leaders take steps to develop self-potential, fostering and increasing performance productivity, including scientific, loyal, skilled, and evaluating their performance to be measured.
\end{abstract}

\begin{abstract}
Abstrak:
Penelitian ini bertujuan untuk menjelaskan kepemimpinan transformasional Dayah dalam pemberdayaan masyarakat Dayah yang difokuskan pada pemberdayaan mutu teungku, santri, dan tenaga administrasi untuk pengembangan Total Quality Management (QTM). Metode penelitian yang digunakan adalah penelitian kepustakaan dengan pendekatan kepemimpinan transformasional pada lembaga pendidikan. Sumber data terdiri dari buku, jurnal, dan sumber literasi lainnya yang terkait dengan lembaga pendidikan Dayah dan kepemimpinan transformasional. Analisis data yang digunakan adalah content analysis dengan menentukan, mendeskripsikan, dan menginterpretasikan data. Hasil dari penelitian ini menunjukkan bahwa dalam memberdayakan mutu teungku, pimpinan Dayah melakukan pengelolaan, pembinaan, dan pengembangan terhadap seluruh teungku dalam dimensi intelektual, spiritual, emosional, dan social. Untuk memberdayakan mutu santri, pimpinan Dayah melakukan penataan segala aktivitas yang berkaitan dengan santri mulai dari input sampai dengan out put dengan serangkaian aktivitas cognitif, afektif, dan psikomotorik. Untuk memberdayakan tenaga administrasi, pimpinan Dayah melakukan langkah-langkah dengan usaha pengembangan potensi diri, pembinaan dan peningkatkan produktivitas kinerja yang meliputi keilmuan, loyal, terampil, dan mengevaluasi kinerjanya agar dapat terukur.
\end{abstract}

Keywords:

Transformational Leadership, Dayah Communities, Total Quality Management 
How to Cite: Almuhajir \& Barus, J. (2021). Transformational Leadership of Dayah: Empowerment of Dayah Community in Developing Total Quality Management. Lentera Pendidikan : Jurnal Ilmu Tarbiyah dan Keguruan, 24(1), 91-105. https://doi.org/10.24252/lp.2021v24n1i9.

\section{INTRODUCTION}

The leader of an educational institution is the backbone of the dynamics of an educational institution, so that the existence, progress, and quality of an educational institution are highly dependent on the leader. Leaders must be creative, competitive, dynamic, not be discouraged, have no weak ideals, and not give up easily (Maris, Komariah, \& Abubakar, 2016). Therefore, leadership capability is a basic requirement of an organization and is crucial to the progress and quality in managing the organization. In addition, the back and forth of an organization depends on the extent of leadership capabilities that affect a leader's ability to manage the organization he leads (Rahim, 2015). Whether an educational institution is successful or not in realizing the vision and mission that has been formulated, the professionalism of the leader is the main responsibility for creating a work climate and culture as well as empowering all existing elements so that they can run according to operational standards.

Graduates are the focal points of destination in an educational institution, and qualified graduates are impossible to reach without a qualified education. To promoting an effective educational institution, strong leaders are needed, and the leaders themselves must have the support of commitment from school personnel such as teachers, staff, and students. One of the required leadership types is transformational leadership. Burns in Rohmat (2010: 66) states transformational leadership is a process of interaction in various activities between leaders and subordinates who seek to achieve higher quality levels of morality and motivation.

Transformational leadership in education has one of its characteristics: leading the institution to change (new directions). At this level, transformational leadership requires visionary leaders. It applies a bottom-up leadership style in managing and developing educational organizations to equate or mention another name for transformational leadership, namely charismatic leadership (Assingkily \& Mesiono, 2019). There are two influential sources of transformational leadership, namely expertise power and reference power. The power of expertise makes it credible and trusted by its members, while the power of reference makes it attractive to its members and unselfish (Setiawan \& Setiawan, 2013: 26).

To realize the transformational leadership of educational institutions to improve the quality of education, a leader needs to carry out integrated quality management or Total Quality Management (TQM). TQM is an approach to maximize competitiveness through continuous improvement of services, human products and the environment (Zahroh, 2013: 92). In addition, Haberer \& Webb (2010: 2) argue that TQM is an allencompassing process, which involves everyone in the organization in identifying and improving every aspect of service and every product. 
Komariah \& Triatna (2010: 8) suggest that the quality of an educational institution can be seen from the achievements of its students, academic and other field achievements, and graduates relevant to the objectives. The school management, teacher profile, learning resources, and environment can be traced through outstanding students. In line with the description, Danim (2010: 53-54) states that quality in education refers to inputs, processes, outputs, and outcomes. The quality of input can be viewed from several aspects. First, whether the quality of human resources is good or not (principals, teachers, laboratory assistants, administrative staff, and students). Second, whether the material input criteria are met or not in teaching aids, books, curriculum, school facilities and infrastructure. Third, whether or not the input is fulfilled in the form of software, such as regulations, institutional structures, and job descriptions. Fourth, the quality of input is in the form of expectations and needs, such as motivation, vision, seriousness, and goals.

In Aceh, one of the hundreds of Islamic educational institutions known as pesantren throughout Indonesia is the Dayah (Siegel, 1969: 48). Even though Dayah educational institution is considered to have similarities with pesantren in Java and surau in West Sumatra, the three educational institutions are not the same, at least from their historical perspective. Pesantren system had existed before Islam arrived and spread in Indonesia. Although anthropologically, Dayah was emerged and born from a religious education process that often occurred in the social interaction environment of the Acehnese people, a good tradition based on Islamic teachings was applied by each individual and community and eventually became a norm order that was obeyed and adhered to, so that it became a learning media.

Dayah is an educational institution for Acehnese local wisdom, has proven its work since pre-independence until now, this is proven by the number of Dayah alumni taking part in the community independently. Dayah has produced many Islamic figures and scholars. Several of them have become scholars and leaders in the community. During the Dutch colonial era, Dayah has produced figures of the struggle willing to sacrifice their body and soul to defend religion, nation and state (Silahuddin, 2016).

At the beginning of its existence, Dayah education institution still referred to as the traditional educational system. However, along with the massive changes and developments of the era and the development of science and technology, Dayah educational institution has made efforts to adapt to existing changes without leaving the old patterns or systems that are still good (Mashuri, 2013).

The aim of forming Dayah educational institutions is to preserve the needs of Acehnese people in the religious field and to control negative things that are not expected to occur in the community. The existence of Dayah educational institutions is also used as a reference for the people in Aceh in providing understanding in social life. In the history of the Acehnese people, Dayah has four functions: first, a media or place for learning Islam and scholars; second, against the invaders; third, development agents; and fourth, community educational institutions (Amiruddin, 2007: 58). 
As an educational manager in Dayah, Dayah leader organizes the Dayah and the working personnel effectively and efficiently. In addition, Dayah leadership is the driving force. It determines Dayah policies for Dayah resources, especially teungku (teachers or educators), santri (students or learners), and administration staff, in achieving educational goals. Thus, it can be said that the success or failure of Dayah activities is largely determined by the quality of the Dayah leadership itself under its management.

In their transformational leadership, Dayah leaders continue to shape and maintain Dayah culture in the dimensions of values, habits, ceremonies, slogans, and various behaviours formed and passed on to the next generation, both written and unwritten. The formed Dayah culture can change and influence the mindset and behaviour of all elements of Dayah, including Dayah leaders, teungku, santri, administrative staff, and parents of students so that the quality of the Dayah is well maintained.

Based on the phenomena, this study explained the transformational leadership of Dayah in the development of total quality management, which focuses on empowering the Dayah community, including empowering teungku as educators, empowering the quality of santri as students and empowering the quality of Dayah administrative personnel. Therefore, the significance of this research was to provide an understanding of the concept of transformational leadership for Dayah leaders in managing their educational institutions based on integrated quality management, as well as to provide understanding or insight for observers of the educational system that Dayah in the realm of national education has undergone many changes following the development of science and technology.

\section{RESEARCH METHOD}

This research was a literature review using an educational institution leadership approach. This study's data sources consisted of books, journals, and other literacy sources related to Dayah educational institutions, transformational leadership, and total quality management with content analysis as a data analysis technique. In conducting content analysis, three stages were carried out, namely determining the themes and keywords sought in literacy that would be researched and studied, consisting of transformational leadership, Dayah communities, and total quality management, then describing these themes and keywords and interpreting data.

\section{RESULTS AND DISCUSSION}

\section{The Essence of Transformational Leadership and Total Quality Management}

A transformational leader is an individual who has a leadership profile that can explain how he leads, changes a team or institution by creating, communicating and modelling a vision and inspiring teachers or other employees to strive to achieve his vision (Sumarto, 2016). The impact on the activities of an organization if the leadership behaviour is transformational can be seen from the transformation of the organization itself. The organizational transformation in question is a change for the better that occurs 
in the organization regarding functions and interactions with its environment, namely significantly increasing organizational performance, generating member commitment to the organization, increasing workers' trust in management and daily organizational behaviour.

Danim \& Suparno (2009: 53) argues that transformational leadership directs and guides human resources that are led to the growing sensitivity of coaching and developing organization, developing a shared vision, distributing leadership authority, and building an organizational culture that is imperative in the organizational restructuring scheme.

Several principles must be considered to create a synergistic transformational leadership in an organization. First, simplification, namely the success of leadership, begins with a vision that becomes a common goal. Second, motivation, which is the ability to influence everyone involved in a vision. Third, facilities, namely in terms of the ability to effectively facilitate staff to develop their intellectuals. Fourth, innovation, namely the ability to be courageous and responsible for making changes. Fifth, mobility, namely the mobilization of all available resources, complements and strengthens each person involved in achieving the vision. Sixth, readiness, namely the ability always be ready to learn about the conditions of the subordinates and to be opened to changes with a new positive paradigm. Seventh, determination, namely getting things done professionally (Hidayat \& Machali, 2010: 102-103). On the other hand, a transformational leader is also required to have three kinds of skills, namely conceptual skills, that is to understand and operate an organization; human skills, namely to work together, motivate and lead; and technical skills, namely skills in using knowledge, methods, techniques, and equipment to complete a specific task (Mulyasa, 2012: 126).

Based on the explanation above, transformational Dayah leadership is a leadership system that tends to carry out actions that always absorb the aspirations of its subordinates (Dayah community, in this case, teungku, santri, and administrative staff) and empower the subordinates to work optimally by involving them directly in compiling programs for the advancement of Dayah educational institution, always pay attention to the needs of their subordinates by trying to create a climate and conditions of mutual trust, mutual respect, sympathy and friendly towards the subordinates, arouse the spirit and participation of subordinates in making policies from various activities by prioritizing active communication. As a result, the growth of respect and self-respect from subordinates to their leaders will increase. Therefore, what becomes the responsibilities is the result of joint decisions and can be carried out as well as possible.

TQM is a philosophy and a methodology to help manage an organization's change, and the core of TQM is the cultural change of the perpetrators. Meanwhile, Slamet (1994: 54) emphasized that TQM is a procedure where everyone continuously improves their path to success. TQM is a management strategy aimed at instilling quality awareness in all processes in an organization. TQM is a management approach for an organization focused on quality, based on the participation of all its members and aims for long-term success through customer satisfaction and provides benefits for all members in the 
organization and society (Vincent, 2001: 22).

According to Sallis in Hidayat \& Wijaya (2017: 176), TQM is a philosophy of continuous improvement, which can provide any educational institution with a set of practical tools to meet the needs, wants, and expectations of its customers, now and for the future. This definition explains that TQM emphasizes two main concepts: a philosophy of continuous improvement and tools and techniques such as field strength analysis, which are used for quality improvement in management actions to achieve customer needs and expectations.

In the context of education, Sallis (2006: 73) explained that TQM education is a philosophy of continuous improvement, which can provide a set of practical tools for every educational institution in meeting the needs, wants, and expectations of its current and future customers. Zamroni (2007: 6) views that improving quality with the TQM model in an educational institution has a role that includes three abilities, namely academic, social, and moral abilities.

Morgan and Murgatroyd in Kristiawan, Safitri, \& Lestari (2017: 135) said that the successful implementation of TQM in educational institutions is based on five keys, namely: First, vision, the idea that an institution wants to achieve, which is abstract and a reflection of the future. Second, strategy and target strategies are broad programs to determine and achieve organizational goals and targets that school institutions pursue. Third, the team, a collection of people who interact and influence each other to achieve the same goal. Fourth, the facilities, physical facilities that function to solve the existing problems. Fifth, the rules, assumptions, and implicit values unite institutions or organizations, including culture, commitment, and communication.

To successfully implement TQM, an educational institution needs to formulate several main principles as stated by Sharples \& Mathews (1989: 142-143), namely responsibility and support, education and training, implementation and practice, standardization and introduction. In addition, several things must be considered in implementing TQM in educational institutions, namely continuous improvement, quality standards, cultural changes, organizational changes, and efforts to maintain good relationships with customers (Zahroh, 2013: 93).

According to Mulyasa (2007: 483-484), there are four main reasons for implementing TQM in educational institutions; including First, educators must be responsible for their duties and functions because educators are the main factor in school improvement. Second, education requires a sensitive problem-solving process and focuses on identifying and resolving the main causes that give rise to these problems and all the roots in educational problems are systemic. Third, the school organization must be a model for the learning organization of all organizations. Fourth, through the integration of TQM in educational institutions, the public can discover why the current educational system is not working well.

Based on the above idea, TQM in Dayah educational institutions is the empowerment of various media and elements in Dayah educational institutions to be 
able to facilitate and meet the needs of customer expectations continuously in the present and future, both internal and external community of Dayah, government, and other stakeholders. Dayah educational institutions have the responsibility of realizing continuous quality improvement. In the development of TQM in Dayah educational institutions, it must be carried out by dayah leaders as managers and all components of Dayah community to support the implementation of TQM in Dayah educational institutions. The involvement of Dayah leaders as managers with transformational systems in the organizations they lead greatly improves the quality of education.

\section{Empowerment of Teungku (Educators) Quality}

One of the components of Dayah community that Dayah leaders must pay attention to developing TQM is teungku. Therefore, Dayah leader must always strive to strengthen the relationship between his/her party and teungku. Developing self-confidence in a Dayah leader has a big role in strengthening the relationship between him/her and teungku. This self-confidence will make full of confidence in facing various conditions. Furthermore, Dayah leader mingles with teungku like friends to realize the general benefit for Dayah. In turn, all of this will make a very large contribution to strengthen social interaction among all individuals.

To be able to improve interaction with a good teungku, a Dayah leader must respect the personality of each teungku. This respectful attitude demands attention to the teungku with all the difficulties they face in Dayah. Appreciating the various opinions and criticisms raised, all of this will encourage teungku to feel they must be more loyal to the Dayah and love their work more, leading to a sincere attitude towards their work. All of this will help realize the various objectives of the educational and teaching process and meet the inner and social needs of teungku. Dayah leaders must also allow Teungku to make various specific decisions related to internal regulations.

In addition, Dayah leaders must also give them some responsibility and consequences by giving them the authority to carry out these responsibilities. Hopefully, all of this will make a big contribution in helping them recognize their roles, obligations, and responsibilities within the scope of the authority given to them.

As-Samâlûthi (2017: 46) that the leaders of educational institutions must always try to dissolve the various disputes between teachers, revive a sense of tenderness, cooperation, and love among them so that the teaching process can produce the expected results. Thus, this can make a big contribution to the student's personality growth. Interaction among teachers has a major influence on interactions among students.

Dayah leaders must help to solve teacher or educator problems because a Teungku cannot overcome the problems while working in Dayah as long as there is no solution. On the other hand, Dayah leadership must help to solve teungku's problems as much as possible. Dayah leaders must be able to map the condition of teungku. When Dayah leader can understand the nature and abilities of all teungku, Dayah leader will know where to put his/her position. Harmony can occur when mutual understanding between Dayah leaders and Teungku affects the relationship between teachers and students positively. 
All of this requires Dayah leaders to have a perfect personality and love for their work, to always be with other people in various work fields, to have the ability, and the courage to make decisions and be sincere in their work. In this way, Dayah leader will be able to attract the trust of Teungku, as well as realize various Teungku desires and realize various educational goals in the context of making a significant contribution to the growth and development of the society. As stated by Mar'at (1984: 7), educators need the services of other people in carrying out their professions; they need a principal in understanding educational goals, curriculum objectives, operational instructional objectives, what they expect and how to provide experiences that suit the needs of learners who are developing.

In organizing Dayah educational institutions, Dayah leaders must understand the characteristics and capacities of teungku to place them in a proportional position or job description and understand what tasks are being completed so that they are not overloaded with their duties. One of the duties of the Dayah leadership is to ensure and create conditions so that teungku believes that the work given contains the five aspects as stated in the National Education department that in principle the teacher will be motivated to do the job given by the principal if he is sure that he will be able to do it, he is sure that the job provides benefits for him, is not burdened by personal problems or other more important or urgent tasks, the task is a trust for the person concerned, and the relationship between friends in the organization is harmonious. By looking at the responsibilities given by Dayah leaders, it shows that there is awareness of themselves. They are aware of improving performance according to the vision and mission of the Dayah institution itself.

The achievement of educational goals in Dayah is highly dependent on the leadership skills and wisdom of Dayah leadership. Dayah leader is a professional office in Dayah educational institutions in charge of managing all organizational resources and collaborating with teungku to educate students to achieve educational goals. With the professionalism of Dayah leaders, the professional development of teungku can easily be realized because it is in accordance with their function as an educator. Therefore, Teungku competence is not only monotonous with the competencies that have been previously owned but develops and increases in a systematic and directed manner so that Teungku professionalism will be realized.

Human resource development is often known as professional teacher development. Referring to the Educational Resources Information Center (ERIC), professional development refers to activities undertaken to enhance a professional career. These activities include self-development, further education, educational services, curriculum preparation, collaboration with colleagues, study groups and training or monitoring with peers (Aedi, 2014: 345).

A Dayah leader must provide positive energy to motivate teungku to carry out their duties responsibly and seriously. A Dayah leader must continue to strive so that his/her advice, suggestions, ideas, and (if necessary) orders or instructions and policies are 
obeyed and followed by all mentored teungku. With high hopes, he/she can make various changes in carrying out various activities, both in attitude, in systematic thinking, and in behaving or acting so that it becomes a necessity for a Dayah leader always to refresh their knowledge and scientific insights so that later they can support their main duties and functions as a leader.

Wahjosumidjo (2008: 97) explained that the leader of an educational institution is one of the educational components that roles the most in improving the quality of education. Therefore, a leader of an educational institution must be a professional person who has a duty as a communication channel in the school environment he/she leads, takes an attitude and is responsible for all actions taken by subordinates, regulates the distribution of tasks quickly and precisely, must think systematically and conceptually, must be able to solve problems through analysis, a mediator, build cooperation through a persuasive approach and agreement, be a diplomat, and be able to make difficult decisions.

Empowering teungku by Dayah leader gets formal juridical support in the Aceh Qanun on the Implementation of Education Number 11 of 2014 subsection 23, namely planning, conducting guidance, improving welfare, providing appreciation and protection, facilitating needs, and the quality of educators in all educational units. Therefore, as mentioned earlier, it can be understood that the Aceh Government assists the leadership of Dayah educational institutions in empowering teungku.

Based on the explanation above, in carrying out the empowerment of teungku quality in the leadership, Dayah leaders must manage and coach all teungku which functions to build, supervise, improve, and seek initiatives and solutions for educational activities by teungku in Dayah. On another part, Dayah leaders also have a role to play in realizing the horizontal relationship of teungku to foster and develop harmonious interactions between individuals so that together they can move towards achieving the goals of Dayah educational institutions through awareness in carrying out their respective duties seriously and responsibly, so that all activities to empower the quality of Dayah educational institutions are largely determined by the role of teungku as educators professionally.

\section{Empowerment of Santri (learners) Quality}

Santri are the axis and target in the learning process and development of the quality of Dayah educational institutions. Therefore, leaders of educational institutions who are personified at the leadership of educational institutions must understand the boundaries of clear and thorough relationships with students. Even though these relationships often turn into routine managerial relationships, such as counting the number of negligence, assessing marks, and reviewing bad behavior, these relationships must have human nuances that pay attention to the personality of the santri.

Dayah leaders who carry out the duties as Dayah managers have a very big role in creating good interactions with students. Dayah leaders must establish various means to strengthen the relationship between themselves and santri and respect the personality of santri by interacting fairly with them. It will give them a sense that they are part of the 
Dayah component. Then, Dayah leaders must also pay attention to the tendencies and constraints faced by santri and create a conducive climate to make communication and dialogue, so that santri feel free to express their various opinions.

This condition fostered the students in Dayah and added to their relationship with Dayah leaders. Al-Hâqil (1414 H: 48) said, "When the leadership of an educational institution meets the various inner and social needs of students, they will surely grow a sense of love, gentleness, and cooperation between them." Therefore, the interest of Dayah is not only focused on the transfer of knowledge but more than that. Dayah leaders must strive to cultivate a good personality with all their potential, especially for themselves and their communities. Therefore, Dayah leaders must pay attention to everything given from the various potentials they have to guide and develop santri as members of society to prepare themselves to face the social order of life. As stated by Muflihah \& Haqiqi (2019), the principal also continues to analyze the suitability of learners' learning outcomes with the vision and mission of the school, learners' needs, and directs educators to adjust the learning program and learning process with the achievement of the vision and mission, as well as with various variables of the needs of learners for further study and even to be able to adapt to social life and the various changes that occur very quickly in social life.

For student empowerment, Dayah leaders can meet the various needs of santri to improve their quality in various ways, including paying attention to the standard of students' knowledge, Dayah activities using various innovations, various directions and advice for santri both inside and outside the classroom, togetherness with the santri in making various decisions related to various Dayah rules, various problems, and discussing and recognizing the students' various perspectives. Martinus and Bunsu in Rahmawati (2018) suggest that the educational process in developing student quality can be done in various ways, including students as a learning centre, learning through experience, developing student reasoning, lifelong learning, and independent learning.

In formal juridical terms, the quality empowerment of santri by Dayah leaders has become a concern of the Aceh government as stipulated in the Aceh Qanun on implementation of Education No. 11 of 2014 subsection 8, namely choosing institutions and/or education fields according to their interests, talents and abilities, obtaining scholarships or tuition assistance for students who excel and/or for learners from economically disadvantaged families, get teaching materials, practicum materials, and other supporting materials.

With the existence of a formal juridical foundation, the quality empowerment of santri must be professionally managed because it is part of a component in a Dayah educational institution that has the same rights as students at other educational institutions. Therefore, the quality empowerment of santri is managed following the rights as learners, including having the right to get potential guidance based on talents and interests, participating in continuing education programs both for self-potential development and for obtaining legality levels/educational institutions, receiving 
assistance from various learning facilities, tuition fees or other assistance under the provisions of the program organizer.

From the above explanation, it can be concluded that Dayah leadership in empowering the quality of santri is an arrangement or regulation of all activities related to santri, namely from the initial process of entry to exit (completion of education) of the santri, with a series of activities that have been planned and carried out consciously and deliberately to foster and organize activities carried out by santri, so that santri in the Dayah feel comfortable and prosperous with the services provided and the learning process in the Dayah can run smoothly, orderly, and regularly so that they can contribute to the achievement of the Dayah's vision and mission and educational goals as a whole.

\section{Empowerment of Administrative Staff Quality}

Administrative personnel is a component of human resources in educational institutions that are indirectly involved in learning activities. Still, administrative personnel existence is very supportive and even determines the smoothness of the learning process activities in an educational institution. They are non-teacher staff who work in educational institutions called "Tata Usaha" (Administration). In the Guidelines for Preparation of National Educational Service Standards Number 053/U/2001, it is stated that school administrative staff are human resources in schools who are not directly involved in teaching and learning activities but are very supportive of their success in school administration activities.

One of the main duties and functions of Dayah leader is to manage the Dayah administration. To complete all main tasks and functions, Dayah leaders can delegate these main tasks and functions to their subordinates who handle administration in Dayah environment. One component that continuously interacts with Dayah leaders and has a vital role in management is the administrative staff.

According to Danim (2010: 208), operationally, administrative staff of educational institution functions and plays a role in administrators in activities, including administration (correspondence, management) of educational institutions related to learning, staffing both teachers and education staffs, managing financial, managing equipment or logistics, managing secretarial and student affairs, maintaining and repairing educational institution facilities. The same thing was also stated by Daryanto (2001: 81), that in general, administrative personnel have three main roles, namely serving the implementation of operational work to achieve the goals of an organization, providing information or information for organizational leaders to make policies or take appropriate actions, and helping smooth organization development as a whole.

Based on the above understanding, Dayah administrative personnel are a component of human resources at Dayah educational institutions who are not directly involved in providing support for the smoothness of learning activities. Still, they serve in general as one of the driving forces for the quality of educational services. Administrative and other supporting activities carried out by administrative personnel have a significant influence on learning service activities, which provide an overview of the performance of the Dayah community as a whole. 
The person in charge of fostering and developing Dayah administrative personnel certainly lies on the shoulders of Dayah leader. The productivity level of Dayah administrative work support for the success of Dayah will impact and be felt directly by Dayah leader as the person in charge. Ugboro \& Kofi (2000) explained that the principal is considered a strong relationship in building the school administration profession.

In empowering administrative personnel, Dayah leaders must pay attention to matters as expressed by Hikmat (2009: 141) that in empowering administrative personnel to improve administrative services, there are several things that principal must consider, including; First, choosing a person who has the requirements and skills needed for a job. Second, placing employees in places and responsibilities under their respective skills and abilities. Third, strive for a pleasant work arrangement and increase workability and maximum results.

Dayah administrative staff need guidance and development from Dayah leaders to maintain and improve the quality, expertise, abilities and skills for the smooth running of professional tasks and maintain dynamic relationships in Dayah educational institutions. Coaching and development activities of Dayah can take the form of training or workshops, mentoring, strengthening or providing motivation, coordination through an open exchange of opinions or suggestions, warning and assistance from Dayah leaders.

Al-Balihisyi (1412 H: 49) said that the leadership of educational institutions always strives to exercise control over their subordinates from the aspect of the division of tasks and supervision of their work. A good relationship that develops based on great respect and appreciation for the various efforts they have contributed. Appreciation and attention to their situation must come from the educational institution's leadership to not burden them with responsibilities that they cannot do. The educational institution leaders must have a dialogue with them using a language and themes that they understand. The management will mobilize their will, enthusiasm, and dynamism to carry out duties with full enthusiasm and love for their work to reflect a beautiful description for the educational institution and its management.

Administrators are part of Dayah. They have a role and self-respect among Dayah community members to positively interact with santri, teungku, and fellow administrative staff. Coaching and developing Dayah administrative personnel to empower their quality, Dayah leaders can carry out various programs to utilize their skills and knowledge, such as training for office technicians or office administration so that changes occur in the organizational system towards a better direction and can improve the performance of each existing administration employee at all levels of Dayah management. To maintain the quality of administrative personnel, Dayah leaders must evaluate them over time to measure their performance.

Daryanto (2001: 182) stated that administrative staff activities need empowerment, motivation, and evaluation of school principals so that their activities can be carried out optimally. The principal must be able to influence that can cause administrative employees to move to carry out their duties effectively to be good. In 
addition, Mulyasa (2012: 64) explained that the efforts made by the leader of an educational institution in empowering administrative personnel were to attract staff interest, develop their potential, pay them, and motivate them to achieve educational goals, help to achieve positions and standards of behaviour, maximize their careers, and to align individual and organizational goals.

Thus, the empowerment of administrative staff carried out by Dayah leaders can encourage them to be more active in carrying out their duties to increase their abilities and foster a sense of responsibility for the tasks assigned to them. Moreover, with administrative staff, Dayah leaders are very helpful in making decisions and taking appropriate actions because they function as an information centre and source of documents and are directly related to the control and responsibility functions of Dayah educational institution.

\section{CONCLUSION}

Dayah transformational leadership is the main central system in a change in Dayah educational institutions. A Dayah leader must have a clear and far-reaching vision and mission, which is to have a holistic picture and bring about a positive academic climate change on how Dayah educational institutions will be in the future by empowering all components of society and understanding the importance of preparing a strong next generation, and ready to face various challenges to realize the ideals of the institution together. The dynamic interaction between Dayah leaders, teungku, santri, and administrative staff plays a very important role, especially in adjusting various Dayah activities with the demands of globalization, societal change, the development of science and technology so that the TQM of Dayah educational institutions are formed to answer all these challenges. To empower teungku quality, Dayah leaders carry out the management, guidance and development of all teungku in intellectual, spiritual, emotional, and social dimensions. To empower the quality of students, Dayah leaders organize all activities related to the students, from input to output, with a series of cognitive, affective, and psychomotor activities. To empower administrative personnel, Dayah leaders take steps to develop self-potential, fostering and increasing performance productivity, including scientific, loyal, skilled, and evaluating their performance so that it can be measured. Therefore, it requires the competence and professionalism of Dayah leaders to generate various benefits for Dayah education institutions, such as stability, progress, development, good image, positive responses from the community, increased achievement and so on.

\section{REFERENCES}

Aedi, N. (2014). Pengawasan Pendidikan: Tinjauan Teori dan Praktik. Jakarta: Rajagrafindo Persada.

Al-Balihisyi, M. S. (1412 H). Al-Idârah Al-Madrasiah baina An-Nadzairiah wa At-Tathbiq. Jeddah: Dâr Al-Bilâd. 
Amiruddin, H. (2007). Ulama Dayah: Pengawal Agama Masyarakat Aceh. Lhokseumawe: Nadiya.

As-Samâlûthi, N. (2017). Dirâsah fî Ijtimaiyyat At-Tarbiyah Al-Islâmiyah (Cet. II). Jeddah: Dâr Asy-Syurûq.

Assingkily, M. S., \& Mesiono. (2019). Karakteristik Kepemimpinan Transformasional di Madrasah Ibtidaiyah (MI) Serta Relevansinya dengan Visi Pendidikan Abad 21. Manageria: Jurnal Manajemen Pendidikan Islam, 4(1), 147-168. https://doi.org/10.14421/manageria.2019.41-09.

Danim, S. (2010). Administrasi Sekolah \& Manajemen Kelas (Cet. I). Bandung: Pustaka Setia.

Danim, S., \& Suparno. (2009). Manajemen dan Kepemimpinan Transformasional Kepala Sekolah. Jakarta: Rineka Cipta.

Daryanto. (2001). Administrasi Pendidikan. Jakarta: Rineka Cipta.

Haberer, J. B., \& Webb, M. W. (2010). Total Quality Manajemen: 50 Cara Agar Efektif Bagi Anda. Jakarta: PT. Indeks.

Hidayat, A., \& Machali, I. (2010). Pengelolaan Pendidikan Konsep, Prinsip dan Aplikasi dalam Mengelola Sekolah dan Madrasah. Bandung: Pustaka EDUCA.

Hidayat, R., \& Wijaya, C. (2017). Ayat-Ayat Alquran Tentang Manajemen Pendidikan Islam. Medan: LPPPI.

Hikmat. (2009). Manajemen Pendidikan. Bandung: Pustaka Setia.

Komariah, A., \& Triatna, C. (2010). Visionary Leadership Menuju Sekolah Efektif. Jakarta: Bumi Aksara.

Kristiawan, M., Safitri, D., \& Lestari, R. (2017). Manajemen Pendidikan. Yogyakarta: Deepublish.

Mar'at. (1984). Pemimpin dan Kepemimpinan. Jakarta: Balai Pustaka.

Maris, I. S., Komariah, A., \& Abubakar. (2016). Kepemimpinan Transformasional Kepala Sekolah, Kinerja Guru dan Mutu Sekola. Jurnal Administrasi Pendidikan, 23(2), 173-188. https://doi.org/10.17509/jap.v23i2.5645.

Mashuri. (2013). Dinamika Sistem Pendidikan Islam Di Dayah. Jurnal Ilmiah Didaktika, 13(2), 259-270. https://doi.org/10.22373/jid.v13i2.477.

Muflihah, A., \& Haqiqi, A. K. (2019). Peran Kepala Sekolah dalam Meningkatkan Manajemen Mutu Pendidikan di Madrasah Ibtidaiyah. Jurnal QUALITY, 7(2), 4863. https://doi.org/10.21043/quality.v7i2.6039.

Mulyasa, E. (2007). Menjadi Kepala Sekolah Profesional. Bandung: Remaja Rosdakarya.

Mulyasa, E. (2012). Manajemen \& Kepemimpinan Kepala Sekolah. Jakarta: Bumi Aksara.

Rahim, M. Y. (2015). Kapabilitas Kepemimpinan Pada Universitas Islam Negeri Alauddin Makassar. Jurnal Lentera Pendidikan, 18(2), 183-193. https://doi.org/10.24252/lp.2015v18n2a4.

Rahmawati, I. (2018). Mengembangkan Kualitas Siswa Sebagai Salah Satu Faktor Peningkatan Kualitas Pembelajaran Sekolah Dasar. Prosiding Konferensi Ilmiah Dasar, 16-18. http://prosiding.unipma.ac.id/index.php/KID.

Rohmat. (2010). Kepemimpinan Pendidikan Konsep dan Aplikasi. Purwokerto: STAIN 
Press.

Sallis, E. (2006). Total Quality Management In Education. Yogyakarta: IRCiSoD.

Setiawan, B. A., \& Setiawan, A. M. (2013). Transformational Leadership: Ilustrasi Di Bidang Organisasi Pendidikan. Jakarta: Rajawali Pers.

Sharples, \& Mathews. (1989). Learning How To Learn:Investigating Effective Learning Strategies. Victoria: Office Of Schools Administration Ministry Of Education.

Siegel, J. (1969). The Rope OfGod. Los Angeles: University Of California Press.

Silahuddin. (2016). Budaya Akademik Dalam Sistem Pendidikan Dayah Salafiyah Di Aceh. Jurnal MIQOT, 40(2), 249-269. https://doi.org/10.30821/miqot.v40i2.296.

Slamet, M. (1994). Manajemen Mutu Terpadu dan Perguruan Tinggi Bermutu. Yogyakarta: Pustaka Pelajar.

Sumarto. (2016). Kepemimpinan Transformasional Kepala Madrasah Di Provinsi Jambi:Studi Multi Kasus Pada MAN Olak Kemang Kota Jambi, Manpulau Temiang Kabupaten Tebo dan Man 2 Kabupaten Tanjung Jabung Timur. Jurnal Lentera Pendidikan, 19(2), 245-259. https://doi.org/10.24252/lp.2016v19n2a10.

Ugboro, I. O., \& Kofi, O. (2000). Top Management Leadership, Employee Empowerment, Job Satisfaction, And Customer Satisfaction In TQM Organizations: An Empirical Study. Journal of Quality Management, 5(2). https://doi.org/10.1016/S10848568(01)00023-2.

Vincent, G. (2001). Total Quality Management. Jakarta: Gramedia Pustaka Utama.

Wahjosumidjo. (2008). Kepemimpinan Kepala Sekolah. Jakarta: Raja Grafindo Persada.

Zahroh, A. (2013). Total Quality Management: Teori Dan Praktik Manajemen Untuk Mendongkrak Mutu Pendiidkan. Jakarta: Ar-Ruzz Media.

Zamroni. (2007). Meningkatkan Mutu Sekolah. Jakarta: PSAP Muhammadiyah. 